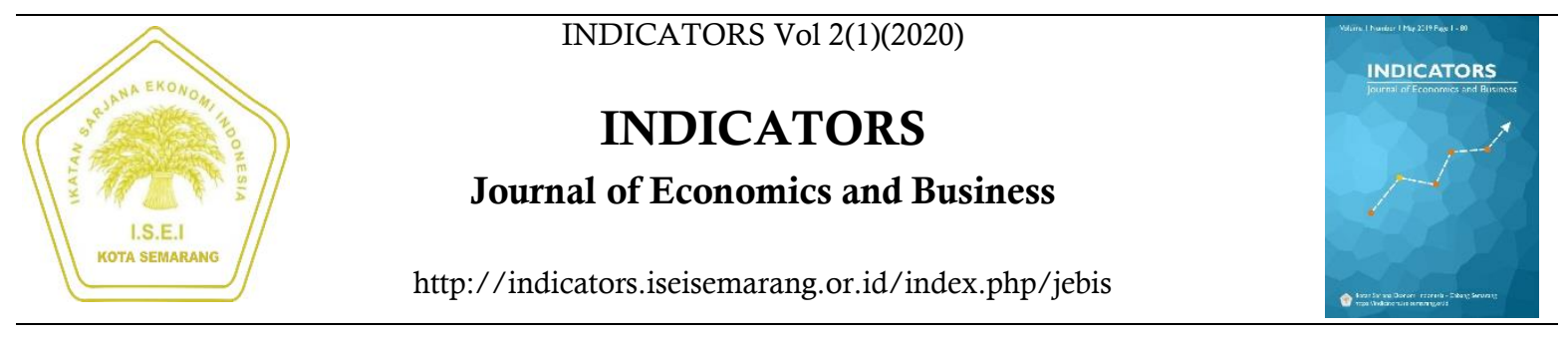

\title{
FAKTOR-FAKTOR YANG MEMPENGARUHI MINAT BERWIRAUSAHA MAHASISWA
}

\section{Ardyanti Nilasari Saputri ${ }^{1}$, Indira Januarti ${ }^{2 凶}$}

1,2Fakultas Ekonomika dan Bisnis Universitas Diponegoro

\begin{tabular}{l} 
Info Artikel \\
\hline Sejarah Artikel: \\
Diterima November 2019 \\
Disetujui Februari 2020 \\
Dipublikasikan \\
Mei 2020 \\
\hline Keywords: \\
Minat berwirausaha, \\
kebutuhan berprestasi, \\
inovasi, kontrol personal, \\
penghargaan diri, \\
lingkungan keluarga dan \\
sosial \\
\hline
\end{tabular}

\begin{abstract}
Abstrak
Penelitian ini bertujuan untuk menganalisis pengaruh faktor internal dan faktor eksternal terhadap minat berwirausaha mahasiswa. Sampel penelitian ini 100 mahasiswa Fakultas Ekonomika dan Bisnis Universitas Diponegoro. Pengujian hipotesis menggunakan regresi berganda. Hasil penelitian ini menunjukan kebutuhan berprestasi, lingkungan keluarga dan sosial berpengaruh positif signifikan terhadap minat berwirausaha mahasiswa. Sedangkan inovasi, kontrol personal, dan penghargaan diri tidak berpengaruh terhadap minat berwirausaha mahasiswa.

\section{Abstract}

This study aims to analyze the influence of internal factors and external factors on the interest of student entrepreneurship. The sample of this study was 100 students from the Faculty of Economics and Business, Diponegoro University. Hypothesis testing uses multiple regression analysis.. The results of this study indicate the need for achievement, family and social environment has a significant positive effect on the interest of student entrepreneurship. While innovation, personal control, and self-esteem do not affect the interest of student entrepreneurship.
\end{abstract}

\footnotetext{
$\triangle$ Alamat korespondensi:

J1. Erlangga Tengah No.17, Semarang, 50229

E-mail: ienjanuarti@gmail.com
} 


\section{PENDAHULUAN}

Kewirausahaan merupakan faktor kunci keberhasilan perekonomian suatu negara. Semakin banyak jumlah wirausahawan di suatu negara, semakin cepat pertumbuhan ekonomi dapat tercapai. Saat ini kondisi jumlah wirausaha di Indonesia belum dapat dikategorikan dalam jumlah yang ideal, namun sudah memperlihatkan peningkatan setiap tahun. Menurut data BPS 2018, jumlah wirausahawan meningkat menjadi $3.1 \%$ dari total jumlah penduduk. Data ini memperlihatkan bahwa masyarakat Indonesia sudah mulai bergerak dan menunjukan peningkatan minat dalam hal kewirausahaan.

Peningkatan minat kewirausahaan ini juga terlihat dari berkembangnya usaha rintisan (Start-up) dari generasi muda. Generasi muda jaman sekarang dipandang memiliki rasa percaya diri yang tinggi, lebih aktif, kreatif, inovatif dan tidak suka dikekang, serta memiliki jaringan pergaulan yang luas karena terpengaruh oleh arus informasi yang semakin pesat melalui teknologi digital. Karakter inilah yang mendorong minat sebagian generasi muda masa kini untuk menjadi wirausahawan daripada bekerja pada sektor formal yang membatasi waktu dan ruang gerak mereka.

Minat seseorang untuk berwirausaha tidak semuanya merupakan bakat yang dibawa sejak kecil atau keturunan, akan tetapi minat yang terbentuk merupakan proses psikologis yang panjang dan dapat dibentuk serta dipengaruhi oleh banyak faktor yang mendukung. Suryana (2006) menyebutkan bahwa faktor-faktor yang mempengaruhi minat kewirausahaan yang pertama adalah faktor internal atau faktor dari dalam individu itu sendiri, dan yang kedua adalah faktor eksternal yaitu hasil interaksi individu dengan lingkungannya.

Beberapa penelitian terdahulu menggunakan model EAO (Entrepreneurship Attitude Orientation) untuk menguji minat terhadap kewirausahaan, namun menunjukan hasil yang berbeda-beda. Penelitian Mathew dan Johnson (2014) membuktikan mahasiswa yang memiliki kontrol personal dan penghargaan diri yang tinggi cenderung memiliki niat untuk berwirausaha. Sebaliknya mahasiswa yang kebutuhan berprestasi dan inovasinya tinggi justru cenderung tidak berminat untuk berwirausaha. Kebutuhan berprestasi (Tong dan Yoon 2011), inovasi (Ismail et al. 2013) mempengaruhi minat berwirausaha mahasiswa di Malasya.

Penelitian yang terkait dengan minat berwirausaha masih sedikit, diantaranya Tong dan Yoon (2011), Ismail et al. (2013) melakukan penelitian terhadap mahasiswa di Malaysia, Mathew dan Johnson (2014) meneliti di Kerala India. Berdasarkan penjelasan di atas, maka penelitian ini bertujuan untuk menganalisis dan memberikan bukti empiris mengenai faktor-faktor yang mempengaruhi minat berwirausaha mahasiswa FEB Undip dengan menggunakan model EAO. Alasan sampel yang digunakan adalah mahasiswa FEB Undip karena beberapa alumni FEB Undip telah berhasil dengan usahanya diantaranya Hasanudin (Freshasan), Novita (House of Moo), Noventia (Takoyaki 48). Manfaat dari penelitian ini diharapkan dapat memberikan masukan kepada fakultas atau pihak terkait lainnya untuk selalu memberikan materi dan fasilitas yang dapat memotivasi mahasiswa dalam berwirausaha.

Minat berwirausaha adalah ketertarikan dalam diri seseorang untuk menghasilkan suatu usaha yang kemudian dapat diorganisir, diatur, dan dikembangkan, serta bersedia menanggung segala resiko yang terjadi (Suryana, 2006). Munculnya kecenderungan ini akibat adanya kemauan dan bakat dalam diri, karakter kepribadian, kepentingan, dan lingkungan yang mendukung munculnya minat tersebut. Teori yang digunakan dalam penelitian ini adalah Theory of Planned Behavior (TPB) yang dikembangkan oleh Ajzen (1991). Theory of Planned Behaviour menunjukan bahwa tindakan manusia diarahkan oleh tiga keyakinan, yakni : (1) Keyakinan perilaku (Behavioral beliefs), yaitu keyakinan tentang konsekuensi atas suatu perilaku yang mungkin terjadi. Keyakinan ini membentuk sikap (attitude) terhadap perilaku. (2) Keyakinan 
normatif (Normative beliefs), yaitu keyakinan individu terhadap pandangan dan harapan normatif orang lain yang menjadi panutannya seperti keluarga, sahabat, dan lingkungan sekitar, serta diiringi dengan motivasi untuk memenuhi pandangan dan harapan tersebut. Keyakinan ini membentuk norma subjektif (subjective norm). (3) Keyakinan kontrol (Control beliefs), yaitu keyakinan individu tentang ketersediaan hal-hal yang memfasilitasi atau bahkan menghalangi perilaku dan persepsi yang terbentuk mengenai sekuat apa hal-hal tersebut dalam memberikan pengaruh terhadap tindakan yang akan ditampilkan. Control belief membentuk persepsi pengendalian perilaku (perceived behavior control).

Kebutuhan berprestasi merupakan pendorong psikologis utama yang memotivasi seseorang untuk menjadi wirausahawan (McClleland, 1961). Dalam teori motivasi, McClelland (1961) menyatakan bahwa orang yang berprestasi tinggi memiliki tingkat kebutuhan yang tinggi untuk pencapaian dan menunjukan diri mereka sebagai pengambil resiko yang moderat. Sehingga mereka lebih suka memilih pekerjaan yang membutuhkan kemampuan dan usaha, membutuhkan feedback, menantang bagi keahlian mereka serta resiko yang tidak terlalu besar. Seseorang yang kebutuhan berprestasinya tinggi memiliki minat berwirausaha karena kewirausahaan menyediakan peluang atau kesempatan dan tantangan yang lebih besar dari pada jenis pekerjaan yang lain. Tong dan Yoon (2011) membuktikan bahwa kebutuhan berprestasi berpengaruh positif terhadap minat berwirausaha mahasiswa.Oleh sebab itu, hipotesis pertama yang diuji adalah sebagai berikut :

$\mathrm{H} 1$ : Kebutuhan berprestasi berpengaruh positif terhadap minat berwirausaha mahasiswa. Inovasi pada dasarnya adalah proses kreatif dalam melakukan sesuatu yang belum pernah ada. Inovasi dalam berwirausaha menurut Robinson (1991) berkaitan dengan persepsi dan tindakan-tindakan yang dilakukan dalam menjalanankan bisnis dengan cara yang baru dan unik untuk memberikan manfaat dan keuntungan yang lebih. Seseorang yang berinovasi tinggi akan cenderung memiliki minat untuk berwirausaha karena berwirausaha memberikan ruang bagi inovasi dan kreatifitas diri tanpa ada batasan-batasan tertentu jika dibandingkan dengan jenis pekerjaan lain. Penelitian Ismail et al. (2013) memberi bukti bahwa inovasi mempengaruhi minat kewirausahaan. Oleh karena itu, hipotesis kedua yaitu :

$\mathrm{H} 2$ : Inovasi berpengaruh positif terhadap minat berwirausaha. Kontrol personal diartikan sebagai kemampuan seseorang dalam mengendalikan kondisi bisnis yang akan dialami (Robinson, 1991). Hal ini juga berarti seseorang memiliki keinginan untuk memberikan pengaruh secara langsung terhadap bisnisnya dan mengendalikan sendiri urusan bisnisnya (Ismail et al, 2013). Dengan kontrol personal yang tinggi, seseorang cenderung menggunakan tingkat kendali atas informasi, sumber daya, dan otoritas yang tepat untuk meraih pencapaian bisnis yang maksimal. Mathew dan Johnson (2014) dan Ismail et al (2013) yang menyatakan bahwa mahasiswa yang mempersepsikan dirinya memiliki kontrol dan pengaruh yang kuat atas binisnya memiliki minat yang lebih besar untuk berwirausaha. Hipotesis ketiga adalah :

H3 : Kontrol personal berpengaruh positif terhadap minat berwirausaha. Menurut Robinson et al. (1991) penghargaan diri (SelfEsteem) merupakan salah satu komponen kepribadian yang mengandung unsur evaluasi atau penilaian terhadap diri, yaitu cara seseorang menilai dirinya sendiri baik positif maupun negatif. Self-esteem yang tinggi akan membuat seseorang menilai dirinya secara positif. Mereka menyadari betul kompatibilitas, kompentensi, serta kelebihan diri yang dimilikinya dan memandang kelebihan tersebut sebagai sesuatu yang jauh lebih berharga dari pada kekurangan dirinya. Mathew dan Johnson (2014) yang membuktikan bahwa penghargaan diri (selfesteem) berpengaruh terhadap minat berwirausaha. Hipotesis keempat adalah:

H4 : Pengahargaan Diri berpengaruh positif terhadap minat berwirausaha. Dalam $\mathrm{TPB}$, norma subjektif mempengaruhi intensi 
individu untuk menampilkan suatu perilaku. Norma subjektif merupakan keyakinan seseorang untuk memenuhi harapan orangorang disekitarnya, baik perorangan maupun kelompok, yang berpengaruh terhadap keputusan dilakukan atau tidak dilakukannya perilaku tertentu. Seseorang akan menampilkan perilaku tertentu ketika ia berpersepsi bahwa orang-orang di sekitarnya yang berpengaruh memiliki pandangan yang positif terhadap perilaku tersebut. Orang-orang tersebut antara lain keluarga, sahabat, tetangga, lingkungan masyarakat, dan sebagainya.

Dalam konteks kewirausahaan, seseorang akan memiliki minat untuk berwirausaha ketika keluarga dan lingkungan di sekitarnya memberikan pengaruh positif terhadap minat itu. Tong dan Yoon (2011) dalam penelitiannya membuktikan bahwa semakin besar dukungan orang tua, keluarga, teman, dan orang-orang sekitar, semakin besar pula intensi (minat) mereka untuk berwirausaha. Hipotesis kelima yang akan diuji yakni:

H5: Lingkungan keluarga dan sosial berpengaruh positif terhadap minat berwirausaha.

\section{METODE PENELITIAN}

Faktor-faktor yang diteliti dibedakan menjadi faktor internal dan eksternal. Faktor internal yang diteliti terdiri dari : kebutuhan berprestasi (X1), inovasi (X2), kontrol personal (X3) dan penghargaan diri (X4). Indikator yang digunakan untuk mengukur keempat faktor internal ini diambil dari model EAO (Entrepreneurship Attitude Orientation) yang dikembangkan oleh Robinson et al. (1991) .

Sedangkan faktor eksternal yang diteliti yaitu faktor lingkungan keluarga dan sosial (X5). Kelima faktor ini ditentukan sebagai variabel bebas (independen). Sedangkan minat berwirausaha (Y) ditentukan sebagai variabel terikat (dependen). Indikator yang digunakan untuk mengukur pengaruh faktor lingkungan keluarga dan sosial (X5) dan minat berwirausaha (Y) diambil dari penelitian Mopangga (2014). Kemudian untuk menilai jawaban responden atas indikator-indikator dalam variabel digunakan skala likert yang berisi 7 tingkat preferensi jawaban dengan teknik pengkodean 1(sangat tidak setuju) sampai dengan 7 (sangat setuju).

Objek dalam penelitian ini adalah mahasiswa aktif Fakultas Ekonomika dan Bisnis (FEB) Universitas Diponegoro. Responden adalah mahasiswa program pendidikan sarjana (S1) akuntansi, manajemen, dan ilmu ekonomi dan studi pembangunan (IESP) yang berjumlah 100 orang dengan teknik Convenience Sampling. Kuesioner yang disebar sebanyak 100 kuesioner dengan tingkat pengembalian $100 \%$. Persamaan regresi linear berganda dalam penelitian ini adalah sebagai berikut:

$$
\begin{aligned}
& Y=a b_{1} X_{1}+b_{2} X_{2}+b_{3} X_{3}+b_{4} X_{4}+b_{5} X_{5}+e \\
& Y=\text { minat berwirausaha } \\
& X_{1}=\text { kebutuhan berprestasi } \\
& X_{2}=\text { inovasi } \\
& X_{3}=\text { kontrol personal } \\
& X_{4}=\text { penghargaan diri } \\
& X_{5}=\text { lingkungan keluarga dan sosial } \\
& b_{1}, b_{2}, b_{3}, b_{4}=\text { Koefisien regresi } \\
& a=\text { Kontanta } \\
& e=\text { Error }
\end{aligned}
$$

\section{HASIL DAN PEMBAHASAN}

Responden terdiri dari 50 orang mahasiswa jurusan Akuntani, 34 orang mahasiswa jurusan Manajemen dan 12 orang mahasiswa jurusan Studi Pembangunan. Ratarata minat mahasiswa Manajemen paling tinggi $(35,74)$ disusul jurusan Akuntansi $(33,63)$ dan Studi Pembangunan (30,86). Jumlah 100 responden terdiri dari 46 laki-laki dan 54 perempuan. Minat berwirausaha laki-laki lebih tinggi $(34,50)$ dibandingkan dengan perempuan $(32,54)$.

Uji instrumen (uji kualitas data) meliputi uji validitas dan reliabilitas. Hasilnya menunjukan bahwa seluruh indikator variabel dalam kuesioner memenuhi syarat validitas ( $\mathrm{r}$ hitung $>\mathrm{r}$ tabel 0,197 ) sehingga kuesioner dinyatakan layak digunakan sebagai alat uji. 
Kemudian hasil uji reliabilitas menunjukan semua variabel dalam penelitian ini reliabel (nilai cronbach alpha $>0,70$ ) sehingga dapat dinyatakan kuesioner yang digunakan handal.

Uji Asumsi Klasik terpenuhi semua. Data residual terdistribusi normal dengan nilai Kolmogorov-Smirnov (K-S) sebesar 0,490 pada sig.0,970. Model regresi dalam penelitian ini juga menunjukan tidak terdapat masalah multikolinearitas karena semua variabel independen memiliki nilai tolerance $>0,1$ dan nilai VIF <10. Model regresi juga tidak mengandung masalah heterokedastisitas karena hasil uji glejser menunjukan nilai signifikansi $>5 \%$.

Besarnya nilai koefisien determinasi (adjusted $\mathrm{R}^{2}$ ) adalah sebesar 0,533 atau 53,3\%. Artinya variabel dependen data dijelaskan oleh variabel independen sebesar 53,3\%. Sedangkan sisanya sebesar $46,7 \%$ dijelaskan oleh faktorfaktor lain di luar penelitian ini. Hasil uji ANOVA nilai $F$ hitung adalah sebesar 23,614 pada tingkat signifikansi 0,000 . Dengan demikian model fit.

\section{Tabel 1. Hasil Uji Statistik t}

\begin{tabular}{llll}
\hline Var & $\begin{array}{l}\text { Coef Std } \\
\text { Beta }\end{array}$ & thitung & \multicolumn{1}{c}{ Sig. } \\
\hline Konst & & $-0,264$ & \multicolumn{1}{c}{0,792} \\
X1 & 0,189 & 1,854 & $0,067^{*}$ \\
X2 & $-0,074$ & $-0,864$ & 0,390 \\
X3 & 0,150 & 1,547 & 0,125 \\
X4 & 0,054 & 0,481 & 0,632 \\
X5 & 0,657 & 9,475 & $0,000^{* * *}$ \\
\hline
\end{tabular}

* Signifikan pada level 10\%

***Signifikan pada level $1 \%$

Sumber : "Data primer yang diolah, 2018"

Tabel 2. Ringkasan Hasil Uji Hipotesis

\begin{tabular}{lll}
\hline $\mathrm{H}$ & Pernyataan & Ket. \\
\hline $\mathrm{H} 1$ & $\begin{array}{l}\text { Kebutuhan berprestasi } \\
\text { berpengaruh positif terhadap } \\
\text { minat berwirausaha }\end{array}$ & diterima \\
& $\begin{array}{l}\text { Inovasi berpengaruh positif } \\
\text { terhadap minat berwirausaha }\end{array}$ & ditolak \\
$\mathrm{H} 2$ & $\begin{array}{l}\text { Kontrol personal } \\
\text { berpengaruh positif terhadap } \\
\text { minat berwirausaha }\end{array}$ & ditolak \\
$\mathrm{H} 3$ & & \\
\hline
\end{tabular}

\begin{tabular}{ll}
\hline H4 & $\begin{array}{l}\text { Penghargaan diri } \\
\text { berpengaruh positif terhadap ditolak } \\
\text { minat berwirausaha }\end{array}$ \\
Lingkungan keluarga dan \\
H5 & $\begin{array}{l}\text { sosial berpengaruh positif diterima } \\
\text { terhadap minat berwirausaha }\end{array}$ \\
\hline
\end{tabular}

Sumber : Data Primer SPSS yang diolah, 2018

Hasil penelitian menunjukkan bahwa kebutuhan berprestasi berpengaruh positif terhadap minat berwirausaha mahasiswa yang ditunjukan dengan nilai koefisien beta sebesar 0,189 dan nilai $\alpha 0,067$ (signifikan pada $10 \%$ ). Kebutuhan berprestasi merupakan penggerak psikologis utama yang memotivasi seorang wirausahawan (McClelland, 1961). Dengan kebutuhan berprestasi yang tinggi, seseorang dapat melakukan sesuatu dengan maksimal dan sebaik-baiknya untuk meraih kesuksesan. Seseorang yang memiliki kebutuhan berprestasi yang tinggi lebih suka memilih pekerjaan yang membutuhkan kemampuan dan usaha, menantang bagi keahlian mereka, memiliki tingkat kesulitan yang sedang dan tinggi, serta memiliki risiko. Berwirausaha merupakan pekerjaan yang tepat bagi orang-orang yang memiliki kebutuhan berprestasi yang tinggi karena kewirausahaan menyediakan peluang, kesempatan, dan tantangan yang lebih besar dari pada jenis pekerjaan yang lain. Penelitian ini memperkuat hasil Tong dan Yoon (2011) yang memberikan kesimpulan bahwa kebutuhan berprestasi berpengaruh signifikan terhadap minat berwirausaha.

Hipotesis kedua bahwa inovasi tidak berpengaruh positif terhadap minat berwirausaha mahasiswa. Hasil regresi di tabel 1 menunjukkan koefisien beta negative sebesar $-0,074$ dengan nilai $\alpha$ 0,390. Inovasi dibutuhkan dalam ruang lingkup atau organisasi yang lebih besar sehingga adanya inovasi mendorong seseorang untuk menghindari kegiatan kewirausahaan (Mathew dan Johnson, 2014). Tidak berpengaruhnya variabel inovasi tersebut disebabkan karena responden dalam penelitian ini belum ada yang berwirausaha. Temuan ini mendukung hasil penelitian Mathew dan Johnson (2014) yang membuktikan bahwa inovasi tidak 
berpengaruh signifikan terhadap minat berwirausaha.

Hipotesis ketiga bahwa kontrol personal tidak berpengaruh positif terhadap minat berwirausaha mahasiswa. Nilai koefisien beta menunjukkan nilai positif $(0,150)$ dengan nilai $\alpha 0,125$. Kontrol personal dalam penelitian ini diartikan sebagai kemampuan seseorang dalam

mengendalikan kondisi usaha yang akan dialami (Robinson, 1991). Tidak berpengaruhnya kontrol personal karena responden belum ada yang menjadi wirausaha.

Hipotesis keempat bahwa penghargaan diri (self-esteem) tidak berpengaruh positif terhadap minat berwirausaha mahasiswa. Tabel 1 menunjukkan hasil koefisien beta 0,054 dengan nilai $\alpha$ 0,632. Dalam konteks kewirausahaan, terbentuknya penghargaan diri (self-esteem) yang kuat merupakan modal yang baik untuk memulai berwirausaha. Untuk mampu melihat peluang usaha yang baik, diperlukan kompatibilitas, kompetensi, dan kelebihan diri. Kemudian melalui keyakinan diri (self-confidence) seseorang dapat merealisasikan peluang usaha tersebut menjadi sesuatu yang bermanfaat atau menjadikan keuntungan baginya. Penghargaan diri (selfesteem) tidak berpengaruh terhadap minat berwirausaha dapat disebabkan responden yang mayoritas angkatan baru sehingga belum memperoleh mata kuliah kewirausahaan, sehingga kurang mempunyai kompetensi yang dapat memberikan keyakinan diri untuk memulai usaha. Hasil penelitian ini bertolak belakang dengan penelitian Mathew dan Johnson (2014) dan Ismail et al. (2013) yang membuktikan bahwa faktor penghargaan diri (self-esteem) dapat mempengaruhi minat berwirausaha

Hipotesis kelima dalam penelitian ini menyatakan bahwa lingkungan keluarga dan sosial berpengaruh positif terhadap minat berwirausaha mahasiswa. Hasil pengujian regresi tabel 1 menunjukkan koefisien beta sebesar 0,150 dengan nilai $\alpha$ 0,000 (signifikansi 1\%). Keluarga memberikan pengaruh awal terhadap terbentuknya kepribadian seorang anak melalui penanaman nilai, norma, dan kebiasaan dalam keluarga. Selain itu perkembangan kepribadian seseorang juga tergantung pada lingkungan sosial dimana seseorang tersebut berada. Kepribadian, pengalaman, dan persepsi lingkungan sekitar dapat mempengaruhi minat seseorang. Minat seseorang dapat terbentuk jika keluarga dan lingkungan sosial terdekat memberikan pengaruh yang positif terhadap minat tersebut, termasuk dalam hal berwirausaha. Hasil penelitian ini juga bertolak-belakang dengan penelitian Ismail et al. (2009) yaitu bahwa latar belakang pekerjaan orang tua tidak berpengaruh terhadap terbentuknya minat berwirausaha.

\section{SIMPULAN}

Hasil penelitian ini membuktikan bahwa faktor internal yaitu kebutuhan berprestasi dan faktor ekternal lingkungan keluarga dan sosial berpengaruh positif terhadap minat berwirausaha mahasiswa. Sedangkan faktor internal inovasi, kontrol personal, dan penghargaan diri tidak berpengaruh terhadap minat berwirausaha mahasiswa.

Karena penelitian ini hanya menggunakan responden dari FEB Undip dengan tanpa memperhatikan apakah responden tersebut sudah memperoleh matakuliah kewirausahaan, maka hasilnya belum data digeneralisasikan. Oleh karena itu penelitian selanjutnya diharapkan untuk memperluas cakupan responden baik dari Fakultas maupun Universitas yang berbeda. Nilai adjusted $\mathrm{R}^{2} 53,3 \%$ sehingga masih $46,7 \%$ variabel lain yang belum diteliti. Oleh sebab itu, diharapkan penelitian mendatang $\mathrm{m}$ menambahkan variabel-variabel lain yang relevan dalam memprediksi minat berwirausaha, seperti faktor kontekstual yang berkaitan dengan adanya pengalaman, pembekalan / mata kuliah kewirausahaan.

\section{DAFTAR PUSTAKA}

Ajzen, I. 1991. "The Theory of Planned Behaviour."Organizational Behaviour and Human Decision $\quad$ Processes, 50(2). 179211. 
Byrd, J dan Brown, P.L. (2003). "The Innovation Equation, Building Creativity, and Risk Taking in Your Organization. San Fransisco: Jossey- Bass/Pfeifer.

Ismail, N., Nahariah J., dan Tan S.H. 2013. "Using EAO Model to Predict the Self Employment Intention among The Universities Undergraduates in Malaysia." International Journal of Trade, Economics and Finance. Vol. 4, No. 5. October. 282-287

Mathew, S.K., dan Johnson, J. 2014. "An Empirical Studi to Predict The Self Employment Intention of Engineering Students Using EAO model in Kerala, India." Proceedings of the Australian Academy of Business and Social Sciences Conference.

McClelland, D.C. 1961. The Achieving Society. Princeton, NY: Van Nostrand.
Mopangga, H. 2014. "Faktor Determinan Minat Wirausaha Mahasiswa Fakultas Ekonomi dan Bisnis Universitas Negeri Gorontalo." Trikonomika. Vol.13. No.1. Hal.78-79

Robinson, B.P., Stimpson, D.V., Heufner, J.C., and Hunt, H.K. 1991. "an Attitude Approach to The Prediction of Entrepreneurship," Entrepreneurship Theory and Practice, Vol.15, no.4, pp.13-31.

Suryana. 2006. Kewirausahaan Pedoman Praktis : Kiat dan Proses Menuju Sukses.Jakarta: Salemba Empat.

Tong, X.F., Yoon, K.T., dan Liang, C.L. 2011. "Factors Influencing Entrepreneurial Intention Among University Students." International Journal of Social Sciences and Humanity Studies. Vol.3. pp. 487-496. 